\title{
CRÔNICAS DO ARAGUAIA: \\ ENTREVISTA COM O ESCRITOR E PESQUISADOR JANAILSON MACEDO
}

\author{
CHRONICLES OF ARAGUAIA: \\ INTERVIEW WITH WRITER AND RESEARCHER
}

\author{
Jacielle da Silva Santos ${ }^{1}$ \\ Janailson Macêdo Luiz ${ }^{2}$ \\ Luiza Helena Oliveira da Silva ${ }^{3}$ \\ César Alessandro Sagrillo Figueiredo ${ }^{4}$
}

\begin{abstract}
Entrevistamos para esse dossiê da ENTRELETRAS o escritor Janailson Macêdo Luiz que publicou, em 2015, o livro Crônicas do Araguaia, o qual remete diretamente a acontecimentos relacionados ao que a história convencionou denominar como Guerrilha do Araguaia. Estamos diante de uma produção inserida na classificação de "literatura de testemunho", mais próxima às vertentes latino-americanas do testimonio e que transita entre a ficção e o fato histórico. Janailson é docente da Universidade Federal do Sul e Sudeste do Pará (UNIFESSPA) e doutorando em História Social pela USP. A entrevista com o autor se deu pelo Whatsapp, em abril de 2020, durante o período da quarentena relativa à pandemia do Covid-19. Seu trabalho se mostra bastante relevante por trazer à memória uma parte da história que, até mesmo por orientação das diretrizes do governo ditatorial (1964-1985) e por uma justiça de transição que não se efetivou, deveria ser lançada ao esquecimento. Em seu relato, trata de seu processo de criação, a relação entre ficção e história, trazendo personagens que perpassam suas narrativas e aludem à memória social em torno dos acontecimentos relacionados à Guerrilha, à tortura, à resistência.
\end{abstract}

Jacielle: Inicialmente, gostaria que se apresentasse e nos respondesse se você se apresenta como alguém que participou de algum modo dos acontecimentos relacionados à ditadura militar.

\footnotetext{
${ }^{1}$ Mestre em Letras pelo Mestrado Profissional em Letras em Rede Nacional (PROFLETRAS/UFT), docente da rede pública de ensino no Tocantins e aluna especial do doutorado no Programa de Pós-graduação em Letras da UFT. Desenvolve pesquisas sobre literatura de testemunho no contexto do norte do Brasil. Membro do GESTO Grupo de Estudos do Sentido - Tocantins. E-mail: jacyla03ale@ gmail.com

${ }^{2}$ Docente da Faculdade de História da Universidade Federal do Sul e Sudeste do Pará, doutorando em História Social pela USP. E-mail: janailson@unifesspa.edu.br

${ }^{3}$ Docente da Universidade Federal do Tocantins, desenvolvendo pesquisas que convergem semiótica discursiva e literatura de testemunho. E-mail: luiza.to@uft.edu.br

${ }^{4}$ Doutor em Ciência Política pela Universidade Federal do Rio Grande do Sul. Líder do Grupo de Pesquisa Violência e Estado. Desenvolve pesquisas sobre Guerrilha do Araguaia, Justiça de Transição, Literatura de Testemunho. Docente da Universidade Federal do Tocantins (UFT), campus de Tocantinópolis. E-mail: cesarpolitika@gmail.com
} 
Janailson Macêdo: Não, eu não participei nem diretamente de acontecimentos relacionados à ditadura porque, inclusive, eu nasci já depois, em 87, dois anos depois do marco que é considerado como final desse processo, o ano de 85 .

Não tive também um familiar diretamente engajado, pai, mãe etc. que tivesse engajado em movimentos sociais no contexto da ditadura. Também não tinha memórias familiares relativas a essas, esses acontecimentos da repressão em si.

É claro que tive parentes que, evidentemente, viveram a época e que tinham uma ou outra lembrança do período, mas não eram muito vinculadas. É diferente de alguém que tenha sofrido determinados eventos mais vinculados à militância política, como, por exemplo, o Paulinho Fonteles $^{5}$, filho do Paulo Fonteles ${ }^{6}$ que era advogado da CPT, deputado. O Paulinho Fonteles nasceu nesse contexto, foi torturado na verdade porque, quando estava ainda na barriga da mãe quando ela foi torturada e os pais foram presos políticos. Eu não tinha pessoalmente esse tipo de memória.

Meu pai era um daqueles retirantes nordestinos que foram para o Rio, para São Paulo. Então, curiosamente, ele relatava aquela cena típica do Nordeste, com o sujeito que sai no pau de arara para o Rio de Janeiro. Assim que chegou no Rio, enfrentou aquelas prisões para averiguação, porque descia um bocado de gente ali perto da feira de São Cristóvão ou outro local específico de que não me lembro. Ele chegou no Rio e foi detido para averiguação como acontecia com muitos, porque os militares já usavam isso como intimidação para população e, também, para ver se tinha algum dissidente político no meio dos migrantes. Ele já é falecido, faleceu mês passado.

Aí quando curiosamente, segundo ele relatava, abriu a mala - eram aquelas malas de madeira de gente bem do interior, na época, no ano de 64, o ano do golpe e quando tinha cerca de 18 anos - só tinha lá o restinho de galinha, rapadura, enfim, e liberaram ele. Tem aquele primeiro constrangimento, então, no máximo memórias relativas ao contexto, mas que não eram memórias nem pessoais e nem familiares relativos à luta armada, por exemplo.

Vamos considerar a questão do Araguaia e a militância política de forma mais ampla. Pelas memórias familiares eu creio que tinha alguns, alguns familiares do meu pai, que chegaram a servir o exército na época, enfim, então imagino que deveriam ter memórias também nesse sentido, mas não conheço esses familiares, não tive contato com eles, faleceram no Rio de Janeiro...

Jacielle: Poderia comentar como foram gerados os dados para criação das crônicas? Gostaríamos que o senhor falasse um pouco do processo de criação dos textos que deram origem ao livro Crônicas do Araguaia.

Janailson Macêdo: Antes de responder a essa segunda pergunta, só queria retomar a questão sobre a memória. Além do que eu falei antes, queria destacar que, em relação à Guerrilha, não cresci na região. Estou dizendo isso porque agora, inclusive, aqui na quarentena, estou na casa

\footnotetext{
${ }^{5}$ Paulo Fonteles Filho. O ex-vereador faleceu em 2017, de enfarto, aos 45 anos. Era presidente do Instituto Paulo Fonteles de Direitos Humanos, escritor, poeta e membro da Comissão da Verdade.

${ }^{6}$ Paulo César Fonteles de Lima, advogado, político, sindicalista, ativista junto a camponeses no estado do Pará e Comissão Pastoral da Terra. Assassinado por pistoleiros em 1987 ligados a UDR (União Democrática Ruralista).
} 
dos meus pais na Paraíba. Meu pai faleceu e eu acabei tendo que vir aqui para dar o suporte nas coisas todas. Sou paraibano. Só fui pra, pra Marabá aos 27 anos quando eu passei no concurso e assumi lá na UNIFESSPA há quase seis anos. Fiz 33, agora. Em julho, completo 6 anos lá em Marabá. Assim, em paralelo à atividade de historiador, professor historiador, o que me fez né, migrar como muitas pessoas, né, o fizeram em outras décadas e ainda o fazem hoje, em paralelo, eu tenho uma carreira literária, com algumas publicações. Tenho um livro de microcontos, de 2012, chamado Micro Fricções e que meu primeiro livro lançado. Tem uma plaquetezinha sobre a história da UEPB, mas, em termos literários, foi o primeiro livro. O segundo foi esse Crônicas do Araguaia. Há um outro livro de contos, que ainda não publiquei. Alguns textos desse volume já tinham sido publicados em revistas, mas não gostei muito do resultado e acabei engavetando.

Eu participo - a gente está, inclusive, fora do ar por enquanto, de um núcleo literário aqui em Campina Grande, na Paraíba, chamado no clube literário Blackout. A gente edita, desde 2008, uma revista literária que vai ser lançada no vigésimo número. Ela é eletrônica e, inclusive, nos próximos dias vai sair o próximo número e o novo site. Está fora do ar temporariamente, mas a gente está recriando a revista em um novo site. Basicamente, essa carreira literária começa quando eu estava na graduação ainda, no curso de história. Tinha alguns amigos como Bruno Galdêncio, João Matias, Flávio Mendes. O Bruno criou a revista e participei desde o primeiro número. Foi quando publiquei meu primeiro conto. Enfim, assim, a gente podia ampliar as sociabilidades literárias, em paralelo.

Para mim, essa atividade não é menos importante. Ainda não consegui me dedicar a ela com mais, maior tempo por causa dessas questões da sobrevivência mesmo. Você tem que fazer concurso, tem que seguir outra profissão de onde eu tiro meu ganha pão e, também, eu acho muito importante. Mas eu considero, de certo modo, atividades que se complementam na minha trajetória.

Estou com alguns projetos literários novos só esperando ter mais um tempinho. Talvez depois do doutorado, enfim, de vez em quando estou rascunhando algumas coisas para poder dar continuidade, porque às vezes a ação, enquanto professor-pesquisador, toma uma energia, um tempo, além da vida familiar também... Mas a ideia é de que tenho pesquisado, estudado mais a fundo questões da ditadura. Continuo silenciosamente, aqui rascunhando os textos e a próxima ideia é a escrita de um romance. Estou com uns livros de contos novos, mas não, não sei se ano que vem já estarão prontos. Vai ser um tempo mais demorado para saírem essas próximas publicações. Enfim, essa parte da resposta foi meio que para contextualizar um pouco né, como é que eu cheguei ao Crônicas do Araguaia. Basicamente, quando eu fui para Marabá, não conhecia ninguém no estado.

$\mathrm{Na}$ verdade, eu conhecia dois escritores. Não conhecia pessoalmente, mas conhecia dois escritores que já haviam publicado nessa revista da qual eu sou um dos editores. É o Abílio Pacheco, que é inclusive marabaense, professor da UFPA, e que mora em Bragança. E o Airton ${ }^{7}$ que é lá de Marabá, que é poeta bem conhecido. Já os conhecia dessa interlocução pela publicação em números da revista Blackout. Não me lembro em que números publicaram, mas o fato é de que não os conhecia pessoalmente.

\footnotetext{
${ }^{7}$ Airton Sousa é poeta paraense, professor, licenciado em História, pela Uniasselvi, e em Letras, pela UNIFESSPA.
} 
Quando eu fui para lá, já tinha a ideia de lançar um livro de contos e a ideia, tentando pensar nas temáticas da nova região onde estou morando. Há o próprio interesse pela Amazônia. Sei que são Amazônias, no plural, mas a gente vai com aquele interesse: "Vou morar na Amazônia". Ao mesmo tempo, há o contato com narrativas, seja em História, seja em Literatura, interessantes, que possam desempenhar junto aos leitores a questão de um contato com as experiências. Eu gosto daquela concepção do narrador do texto de Walter Benjamin.

Tinha essa ideia: "Meu projeto vai ser um livro de contos". Não sabia ainda qual seria e aí, em 2014, tive contato com toda aquela efervescência sobre a memória da Guerrilha em virtude da Comissão Nacional da Verdade. Inclusive, logo que eu cheguei à cidade, assisti audiências na UNIFESSPA, com o auditório lotado com pessoas da sociedade em geral, familiares de camponeses que haviam sido torturados e acabaram tendo que colaborar com os militares no contexto da Guerrilha. Passei a ter contato maior com a literatura em relação à Guerrilha, no caso, a literatura correspondente à produção científica a respeito do tema. Fiquei muito impactado assistindo a uma das audiências. Embora não tenha sido o primeiro conto escrito, a ideia para o conto "Fantasma da Casa Azul" surgiu mais ou menos nessa hora, nessa audiência, quando um dos senhores que moram em Marabá levantou disse algo mais ou menos assim diante do auditório lotado, mirando para uma filmadora: “Olha, estou aqui falando para vocês, mas foram lá na minha casa, me procuraram e disseram que eu não falasse muita coisa porque, enfim, poderia acontecer algo comigo, com minha integridade física”.

Eram muitas narrativas pesadas às quais já era acostumado, mas que naquele dia, assim, eu senti como algo impactante. Era a questão da memória social, porque uma coisa é a narrativa literária, outra coisa a narrativa histórica, outra coisa que pode até englobá-las também é a questão da memória social. Senti muito forte aquelas narrativas ali, estar vivendo ali, no meio das pessoas que vivenciaram e ainda vivenciam aquele trauma mais de 35 anos depois e isso me impactou. A ideia do "Fantasma da Casa Azul" não é literalmente o depoimento desse senhor, mas eu me inspirei, por exemplo, em casos como dele que são muitos. Muitas pessoas dizem, que relataram e relatam que continuavam sob certa vigilância. Então, isso de certa forma inspirou o relato. Não cheguei a fazer uma entrevista com esse depoente, mas seu relato me inspirou a construção do conto, embora não tenha sido o primeiro a ser escrito.

Ainda continuando essa resposta, falando mais agora desses dados, havia um edital na UNIFESSPA na época que era em apoio a publicações, um concurso. Eu acabaria vencendo esse concurso, ficando em primeiro lugar. O Airton ficou em segundo e o pessoal - um coletivo lá de estudantes, de meninas - ficou em terceiro. A gente tinha que para concorrer a esse edital fazer uma, um pequeno projeto e além desse pequeno projeto tinha que elaborar dois contos. Esses contos vieram rapidamente à cabeça. Assim, juntando o projeto que eu já tinha para essas narrativas todas, enviei o conto "Cova Cristã", numa versão diferente da final e o "Do outro lado da floresta", que fecha o livro.

Esse "Cova Cristã", por exemplo, foi uma notícia que eu li, não lembro se de um dos mateiros, dos guias que colaboravam com os militares, dizendo que, na época, tinha que cavar os locais para enterrar os guerrilheiros na mata como uma cova cristã - a sete palmos. Existe, existiriam, não sei, outros tipos de covas, mas eu achei curioso o termo "cova cristã". Estava lá numa entrevista, então, criei o conto, fui refazendo, enfim, o dado existia, vem de uma narrativa anterior. Mas não utilizei diretamente essa narrativa, criei uma coisa nova a partir dos 
referenciais de outras leituras sobre o tema, sobre outras leituras literárias também, que não se encerram somente ali na Guerrilha.

"O Fantasma da casa azul" também acabaria ativando um pouco aquela memória daquele primeiro depoimento e recriando uma outra coisa mais. Os contos fazem parte dessa memória social, remetem à memória social. Então, não seria necessariamente a narrativa daquele senhor específico que falou no auditório, mas, de certa forma, a conexão com narrativa de pessoas que continuavam sob vigilância, no caso do "Fantasma da Casa Azul".

Esse da "Cova Cristã" não necessariamente trata daquela pessoa da notícia, pois, infelizmente, foi algo que se passou com vários dos mateiros. Fui em busca de informações e o lado historiador ajudou bastante, porque eu já estava ali inserido, já tinha contato com as obras. Fui comprando obras. Na medida em que foi aprovado e que eu tinha esses dois contos, tive que fazer os outros, pois eu não tinha na verdade os outros contos. Tinha ideia de alguns, mas eu não tinha os outros contos, todos. Acabei escrevendo até mais do que os que foram publicados, mas eu achei que os 12 que estão publicados correspondiam... Tem isso, se você publica um livro de contos, ele tem que ter uma certa coesão dos textos entre si, senão seria uma mera coletânea e a ideia não era uma coletânea de contos, mas um livro cujos textos dialogassem, tivessem um certo diálogo entre si. Não como um romance, ou seja, eles não tão concatenados, mas fazem parte de uma mesma atmosfera, digamos assim.

Vou abrir aqui o índice. Esse conto "Judiaria". Até o Johnny Martins, que fez a revisão do texto, disse: "Mas esse termo não é pejorativo em relação aos judeus?".

Aí não, não é judiaria por causa dos judeus, mas porque as pessoas da região costumam chamar assim os atos de tortura, que sofreram de judiaria por causa da judiação. São por causa do termo judiação. Eu não sei a etimologia se mais a fundo isso tem a ver com a questão judaica, mas era mais ou menos esse significado que eu tentei capturar. Esse texto "Judiaria" é, inclusive, dedicado a seu Beca ${ }^{8}$.

Fiz entrevista na época, conversei com pessoas que viveram a época, com filhos também, mas sobretudo com camponeses que haviam sido torturados. Posteriormente, tive contato com familiares de guerrilheiros e, inclusive, na minha pesquisa de doutorado agora, entrevisto alguns deles também, no caso, delas pois entrevistei mulheres, como as irmãs da Helenira Rezende ${ }^{9}$, por exemplo. Na época, eu não tinha ainda contato de memórias que estavam em publicações, mas entrevistei pessoas.

O seu Beca entrevistei alguns dias antes de ele morrer. Ele morreu doze dias depois que eu entrevistei. O conto não tem nada a ver com a entrevista dele, assim, literalmente. Ele falou das experiências dele que não são as mesmas experiências dos personagens do conto. Esse conto foi, inclusive, lido numa rádio lá em Marabá. Achei interessante, mas não ouvi. Soube pelas pessoas que me contaram depois. Eu achei muito legal. Num evento público, o próprio Airton fez um elogio a esse conto. É claro que eu tenho ciência de que os textos são produzidos por um escritor que estava iniciando, tem seus problemas também, mas eu gostei dessa, ainda que mínima, mas boa repercussão que teve. E é justamente essa questão das experiências.

\footnotetext{
${ }^{8}$ Apelido de Euclides Pereira de Souza, torturado pelos militares na ditadura.

${ }^{9}$ Helenira Rezende de Souza Nazareth, codinome Fátima, foi militante do PCdoB, estudante de letras da USP, vice-presidente da UNE nos anos 60, incorporou-se a Guerrilha do Araguaia no início dos anos 70, vindo a ser assassinada em confronto armado pela corporação ação militar em 1972, seu corpo nunca foi encontrado.
} 
Seu Beca foi preso na base lá em Xambioá, não viveu exatamente aquilo que tá ali narrado, mas coisas tão dramáticas quanto. Ser jogado lá, no buraco do Vietnã, ser torturado, enfim. Então, não é a mesma coisa que os personagens que é um pai e um filho viveram, mas existem outras pessoas que tinham essas memórias. Existem memórias de filhos que viram pais sendo torturados e pais que viram os filhos sendo torturados e até mortos. Desse modo, o conto não se refere a um caso específico, mas faz um link com essas memórias tidas em relação à Guerrilha.

Para os dados, fiz essa consulta, essa parte da pesquisa que eu penso que muitos escritores o fazem, inclusive fiz um curso ano passado, em São Paulo, com a escritora Carol Bensimon ${ }^{10} \mathrm{e}$ ela defende muito essa questão da pesquisa na produção literária. Muitos, muitos o fazem no sentido diferente da pesquisa, por exemplo, que eu faço em história, onde tem que ter a fidelidade do relato, a menção, enfim. No caso, era muito mais uma questão de atmosfera, digamos assim, das experiências, mas não é propriamente a experiência que o próprio seu Beca vivenciou, mas é muito próximo. Essa é a questão, ou seja, aquele contexto tinha tanta atrocidade que aconteceram coisas piores do que as que são relatadas nessas obras.

Ainda com relação a essa questão dos dados, eu queria chamar atenção para questões que não dizem respeito necessariamente somente ao universo da guerrilha do Araguaia e da ditadura. Por exemplo, para o conto "Enxoval, duas inspirações na época da escrita desse livro foram o livro que citado na epígrafe que é o Exército de Cavalaria, do Isaac Babel ${ }^{11}$, escritor russo, que inclusive traz a ideia de crônicas. O livro é de contos, mas eu coloquei o nome no título de crônica um pouco no sentido dessa própria epígrafe, tentando remeter um pouco à ideia antiga de crônica. $\mathrm{Na}$ época, não existia um relato histórico como a gente entende hoje a crônica, mas tinha uma significação diferente dessa feita no domingo nos jornais que foi a que se consagrou aqui no Brasil com Rubem Braga e outros.

Lembremos daqueles textos recentes que fazem referência a esse tipo de publicação que tinha mais relação com a memória, como, por exemplo, as próprias Crônicas de Gelo e Fogo ${ }^{12}$, As crônicas de Nárnia ${ }^{13}$. Trago essa ideia de crônica como os relatos do que teria acontecido no passado de um povo, só que no caso literalizado. Esse livro do Isaac Babel, na época, tinha muita influência e quero retornar a ele daqui a pouco para novas leituras, pois me fez muito pensar na parte estética, inclusive, ainda que eu não tenha necessariamente o mesmo estilo que ele, mas me inspirou bastante na escrita. Lembro então que são contos. E a história de vida dele é muito complexa. No contexto pós revolução russa, ele era um jornalista, também literato, judeu que acompanhava o Exército Vermelho que era o exército dos que haviam feito a revolução na guerra civil contra o exército que representava as forças conservadoras do próprio czar que foi derrubado ${ }^{14}$.

\footnotetext{
${ }^{10}$ A escritora, nascida em 1982, em Porto Alegre, foi finalista em 2018 do prêmio Jabuti de melhor romance pela publicação de $O$ clube dos jardineiros de fumaça, pela editora Companhia das Letras.

${ }^{11}$ Escritor de origem judaica, nascido em 1894 e morto em 1940, executado pelo governo stalinista.

${ }^{12}$ De autoria de George R. R. Martin.

${ }^{13}$ Série de C. S. Lewis.

${ }^{14} \mathrm{O}$ autor faz referência à Revolução Russa, de 1917, que derrubou do poder o czar Nicolau II.
} 
Babel foi alguém que escreveu enquanto os acontecimentos estavam sendo vivenciados, mas escreveu em formato literário. A própria história de vida dele é bem complexa, bem interessante. Há outras referências, como o chamado Vá e veja ${ }^{15}$ que é um filme da década de 80 sobre a Bielorússia que retrata a questão da ocupação nazista, com uma série de atrocidades que os nazistas fizeram lá. Esse filme Vai e veja não corresponde ao formato dos filmes estadunidenses, ou mesmo ao italiano $A$ vida é bela, com aquela catarse no final que apela mais para o drama, como aquela cena do pai, que tenta fingir pro filho que não tá acontecendo algo muito atroz, como se tudo fosse uma grande brincadeira e tal, mas no final como era de se esperar, ele morre e o filho... Você vê aquela sensação típica de uma catarse.

$\mathrm{Na}$ verdade, esse filme é muito porque mostra o terror que foi a ocupação e a guerra entre o pessoal da Bielorrússia contra os nazistas, quando usaram de artifícios de guerrilha porque os nazistas atacam a população camponesa os próprios camponeses têm que se unir para poder fazer movimentos de resistência. São atrocidades próprias de uma guerra e próprias do que os nazistas fizeram em vários locais lá da Europa. Então, assim, é um filme que me chocou bastante, assim. Essas duas narrativas, a do Isaac Babel e do Vá e veja influenciaram também a produção do livro no sentido da inspiração pois foram obras que estavam na cabeceira durante aqueles dias de produção do Crônicas de Araguaia.

"Enxoval" é bem atmosfera dessas outras narrativas a que fiz referência, havendo, então, um pouco dessas conexões com a realidade do sul e sudeste do Pará. Essas situações ficcionais, permitiram links, pontes com situações reais, contextos reais de violência exacerbada no século 20 e muito marcadas também pelo próprio autoritarismo, impacto desse autoritarismo junto as populações camponesas, sobretudo.

"Despedida" e "Do outro lado da floresta" falam mais dos guerrilheiros, militantes e, para isso, tomei outras leituras sobre o tema. Salvo engano, esse texto "Despedida" foi um dos últimos a serem escritos. O "Desenhando Laura" também foi um dos últimos. "Pedaço de mim" de Chico Buarque, citada na epígrafe, estava ouvindo também e serviu de mote. Como a gente diz na poesia popular do Nordeste, o pessoal lá do cordel, isso aqui pode ser um mote para uma história também a partir dessa questão dos familiares dos mortos desaparecidos.

Jacielle: Qual a relação que você estabelece entre verdade e ficção?

Janailson Macêdo: A terceira pergunta é muito difícil. Digamos que de fato aconteceu aquilo que é recriado, reinventado. "Crônicas do Araguaia" não é um livro de história. Ele é diferente de um livro de história no sentido de que sejam acontecimentos reais e algumas pessoas até sejam reais. O Osvaldão ${ }^{16}$, que é citado em um dos contos, era um personagem real. No conto "O sonho" há referência a um acontecimento sobre um dos chafurdos que eles sofreram e foram atacados e que muito possivelmente alguns elementos que estão ali se aproximam da realidade dos fatos, enfim...

Só que isso não, não faz com que sejam uma obra de história. Essa obra não tinha essa intencionalidade de ser fidedigna na escrita em relação aos acontecimentos em si, mas dialogar

\footnotetext{
${ }^{15}$ Filme russo dirigido por Elem Klimov, 1985.

${ }^{16}$ Referência a Osvaldo Orlando da Costa (1938-1974), uma das principais lideranças da Guerrilha do Araguaia. Assassinado por militares, seu corpo nunca foi encontrado.
} 
com a memória social a respeito da Guerrilha do Araguaia. É um movimento diferente do que estou fazendo na tese, que vai ter um capítulo específico para o Osvaldão, porque lá vou debater explicitamente com os textos que falaram sobre ele, com as fontes. Eu gosto da ideia de rastro, de vestígio de rastro. A partir do filósofo francês Paul Ricoeur, em seu livro A memória, a história e o esquecimento $^{17}$, vejo ali o papel da narrativa, seja ela qual for, é a questão da humanização do tempo. Pode ser uma narrativa histórica, pode ser uma narrativa literária ou de outros gêneros, trata-se de humanizar o tempo. Você falar o ano de 1972 é uma coisa. Se você disser algo como "Em 72 aconteceu um dos eventos mais marcantes da história do Brasil” já é outra coisa, "no ano 72 foi lançado o livro tal..." As narrativas humanizam o tempo, mas o fazem de formas diferentes. A escrita da história tem o papel de analisar os testemunhos, mas também fazer a crítica dos testemunhos. A gente tem que cruzar fontes entre si, visando à produção de uma verdade, mas a ficção pode dialogar de outras formas. Ela pode ser uma ficção baseada em fatos, nesse caso, aqui é um livro baseado em fatos, mas que não tem esse, esse intuito de ser, necessariamente, esse movimento de testemunho e crítica do testemunho. Li bastantes narrativas de testemunho, como do Glênio Sá ${ }^{18}$, uma obra pouco analisada no sentido da produção sobre testemunho, sobre a guerrilha que é o relato de um guerrilheiro. É um pouco nesse sentido, são movimentos. Entendo que são movimentos diferentes seja na parte da escrita e da produção em si, ou seja, a escrita em História. A gente começa essas escritas lançando perguntas, depois montando um arquivo de fontes, depois fazendo uma análise dessas fontes a partir da pergunta e produzindo um texto que ele vai ter elementos literários, mas vai tá atrelado essas outras duas etapas como cita o Paul Ricoeur. A produção literária pode até pode dialogar algum momento com essas etapas, mas a questão é mais a produção em si do texto.

O texto tem, de certa forma, que fazer alusão a essas outras questões externas, tem que se sustentar mais por si. É claro que a gente sabe que o texto evoca, que só vale a pena porque ele vai evocar a memórias das pessoas, sentimentos, emoções. Embora a gente saiba como uma série de autores já abordou também que dentro da produção voltada mais para a história, pra uma questão de verdade, existem tons que são da imaginação de quem tá produzindo. Veja, por exemplo $O$ queijo e os verme ${ }^{19} s$, que é uma obra clássica em história, a partir dos pontos que são tão presentes nas fontes, mas também nas brechas deixadas. O Carlos Ginzburg, historiador italiano, faz uma análise brilhante usando muito a imaginação. São produtos diferentes e que inclusive remetem a leitores que conseguem transitar por gêneros diferentes. Imagino que alguém que vai pegar o Crônicas do Araguaia, pode ativar as experiências que tem em relação ao tema, alguém que de repente vivenciou, ou os pais vivenciaram isso, ou alguém próximo. Ele vai dizer - "Nossa, isso aqui dialoga com a experiência que a minha família teve. Mas não é necessariamente a narrativa do meu avô sobre isso, do meu pai sobre isso".

Essas distinções são difíceis, mas a ideia é pensar a partir da memória social, que ela foi feita aqui de forma ficcional. Aquilo que já havia sido publicado em fontes, em depoimentos, em

\footnotetext{
${ }^{17}$ RICOUER, P. A memória, a história, o esquecimento. Trad. Alain François [et al.]. Campinas, SP: Editora da Unicamp, 2007.

${ }^{18}$ Referência ao militante do PCdoB Glênio Fernandes de Sá (1950-1990), autor de Araguaia: relato de um guerrilheiro, publicado pela editora Anita Garibaldi (1990).

19 A publicação do historiador italiano Carlo Guinzburg em 1976 trata das ideias e do cotidiano de Domenico Scandella, moleiro perseguido pela Inquisição, no século XVI. No Brasil, a tradução de Il formagio e il vermi foi publicada pela Companhia das Letras.
} 
testemunhos, em obras de história, inclusive, serviram de referência para a leitura e depois para a produção de uma outra coisa que foi o livro. Não sei se eu respondi com precisão, mas é mais ou menos essa forma como eu entendo, né, essa relação...

Eu vou muito por essa linha do Paul Ricoeur e do Walter Benjamim. O que as duas podem oferecer em comum é aquilo da experiência do narrador, estão presentes ou podem estar nos dois tipos de escrita. Você pode ter uma obra de história que seja só sobre método quantitativo e que não vai falar muito de experiência, vai falar de números, de algo muito macro. Mas também há obras literárias que têm experimentações diferentes. A grande questão talvez seja o a experiência e a própria questão de narrativa, de humanização também. Ler uma obra que trata desse tipo de tema ajuda você também a compreender, ainda que não seja uma obra verídica, os acontecimentos em si, porque dialoga com essa memória, literatura dialogando com essa memória social de uma forma mais ampla.

Jacielle: Qual sua relação com os sujeitos que narram os fatos? Como foi o momento da geração dos dados? Foi diretamente com os sobreviventes? Eles tiverem dificuldade em narrar? Como foi o primeiro contato que o senhor teve com eles? Incluiu filhos dos sobreviventes, ou pessoas próximas aos sobreviventes?

Janailson Macêdo: Acho que em parte já respondi, mas vou acrescentar mais dados aqui. Não tive em relação a esse tema, memórias de infância. Não tinha militantes na minha família, ou também eu vivia muito longe da região, enfim. Mas também, tinha relatos de outras atrocidades envolvendo racismo, envolvendo questões de violência aqui, no Nordeste, que certamente me ajudaram a seguir um pouco por esses caminhos, esse tipo de narrativa que eu venho produzindo em relação à literatura sobretudo da parte desse livro. Por exemplo, no Mestrado em História, como historiador e na graduação, tive contato com memórias de quilombolas aqui na Paraíba que eram muito pesadas também, com relatos de muita violência que eles sofreram. De certa forma, as leituras iniciais sobre memória também vieram daí. Fazem parte, mas não diretamente estão vinculadas ao contexto da Guerrilha.

Alguns professores contribuíram no sentido de empréstimo de livros também, como é o caso da professora Rita. Fiz uma viagem de campo com a turma dela da Educação do Campo quando pude entrevistar algumas pessoas. Essa viagem compreendeu várias cidades do Sul e Sudeste do Pará e Xambioá, no Tocantins. Essa viagem que ocorreu mais ou menos em 2015 serviu muito de aprendizagem. Além do seu Beca, entrevistei outras pessoas também que haviam vivido acontecimento diretamente, que haviam sido torturadas. Depois da escrita do livro é que eu entrevistei mais pessoas, mas até esse momento, dezembro de 2014 eu não havia entrevistado pessoas, só assistido essas audiências de que eu falei e lido a respeito.

Também tinha procurado reportagens, assistido a documentários, como o do professor Evandro $^{20}$, Araguaia, Campo Sagrado, no qual seu Beca é um dos personagens centrais do documentário. Houve ainda o Camponeses do Araguaia, de direção do Vandré Fernandes. São obras que falam dos camponeses e com as quais tive contato também. Pude entrevistar homens, mulheres, em Xambioá, em São Geraldo, São Domingos, mesmo em Marabá, e que me

${ }^{20}$ Evandro de Medeiros, docente da UNIFESSPA. 
ajudaram. As narrativas foram incríveis. Tive problemas com o HD onde ficaram registradas entrevistas como a do seu Beca já muito idoso, cansado doente e que conversou comigo, que ficou até umas onze da noite falando.

Você disse que estavam discutindo, na sua turma o livro do Primo Levi ${ }^{21}$. E eu percebi neles algo que no Primo Levi é muito forte, a questão da necessidade de narrar. Quando o Primo Levi volta para a liberdade, após ter vivido lá em Auschwitz, no campo de concentração, as pessoas não entendiam aquele tipo de narrativa, já não tinham mais a paciência. Não havia interesse de escutar aquelas narrativas e o livro é movimento todo em relação à necessidade de expor as memórias do que aconteceu. Percebo que algumas pessoas, por vergonha, por trauma, optaram por não falar. Morreram sem falar ou até hoje não falam com medo de represálias ou porque alguns colaboraram também com os militares, receberam terras. Mas outras delas tem essa veia que o Primo Levi traz, essa questão da necessidade de narrar e o seu Beca era um deles. Depois, entrevistei a senhora Neusa ${ }^{22}$. Teve uma das entrevistas eu terminei quase à meia-noite. Depois a outra era mais de uma da manhã. Você fica naquela situação constrangido: "Nossa, estou na casa da pessoa, é 1 h30 da manhã e a pessoa tá falando, falando, falando". Foi literalmente o que aconteceu. Eu já estava constrangido. Teve, por exemplo, essa senhora que ela era a esposa do... Ela está nesses documentários todos também, acho que não tem problema eu falar o nome dela.

No livro não há referência às experiências do seu João, que depois vai participar da Batalha dos Perdidos e com quem conversei bastante. Fizemos entrevistas também com Precatão ${ }^{23}$, em Xambioá. Foram narrativas muito ricas. Com relação a do seu Beca, estávamos em frente à casa dele, já um pouco escuro, por volta de $11 \mathrm{~h} 30$ da noite e me lembro de ver o gesto que fazia para mostrar que não conseguia fechar os braços, atualmente, por causa do pau de arara. A tortura ficou marcada no corpo dele. Estávamos à meia-luz, o rosto dele saindo um pouco da luz e dizendo: "A gente ficava conversando assim como a gente está agora, olhava pro chão tinha uma pessoa deitada, que era geralmente algum militar infiltrado. Eles ficavam espiando o que as pessoas estavam conversando nas casas. Imagina só, você está conversando com uma pessoa de noite quando olha pro lado há um cara deitado. Você nem pode dizer que está vendo o cara, tem que fingir que não está vendo, porque sabe que é um militar infiltrado ou alguém que foi colocado ali para vigiar".

No caso dos dois e dessas outras pessoas eu não vi muito a questão da hesitação. Eles falaram bastante, falaram muito, até porque, inclusive, já tinha esse contato com outros pesquisadores, como o próprio Paulinho Fonteles. Não lembro se o Paulinho Fonteles estava em um desses depoimentos comigo lá também, mas ele era uma pessoa que abria também muitos caminhos. Estavam lá falando com professor da Universidade e já tinham tido experiências positivas a partir do trabalho do professor Evandro, por exemplo, e desses outros documentários.

$\mathrm{Na}$ pesquisa posterior a essa, tive experiências mais pesadas, quando pessoas falaram muito profundamente. A Neusa, se não me engano, foi casada com Amaro, militante que se apaixona

\footnotetext{
${ }^{21}$ Referência à disciplina ministrada em 2020 no Programa de Pós-graduação em Letras da UFT, campus de Araguaína, que, dentre os textos selecionados, discutiu a respeito de um dos principais exemplares da literatura de testemunho vinculada a Shoah, É isto um homem?, do escritor italiano Primo Levi.

${ }^{22}$ Neusa Lins, viúva de Francisco Amaro Lins, militante preso pelos militares em 1972.

${ }^{23}$ Pseudônimo de Antônio Alves de Souza, torturado pelos militares durante a Guerrilha do Araguaia.
} 
por ela. Amaro tinha uma idade um pouco mais avançada que os outros, que boa parte dos outros guerrilheiros. Ele então decide não participar da Guerrilha como um agente da luta armada, mas fica ali na região morando com ela e de certa forma ele acabou sendo um apoio quanto a informações. Depois que acabou a Guerrilha, ficaram vivendo no interior da mata uns 10 anos ainda. Algo assim. Muito tempo! Achei recentemente um filme na Netflix que fala de sujeitos perseguidos pelo regime franquista, apelidados de "toupeiras", que, acabados os conflitos armados, ficaram 30 anos morando escondidos dentro de casa, em buracos.

Foi algo que aconteceu no Araguaia também com essa família. Eles ficaram cerca de 10 anos escondidos, mesmo depois do fim.

Outro exemplo é o do Zezinho do Araguaia ${ }^{24}$, guerrilheiro, que ficou escondido em São Paulo durante também mais de 10 anos. Só já nos anos 90, né, quase 20 anos é que ele veio se apresentar e ajudou a retomar um pouco das memórias a respeito da guerrilha. Penso que essas experiências de contato com pessoas também foram muito importantes justamente pela experiência. Com uma notícia de jornal ou num livro você pode ler sobre a experiência, mas estando ali com a pessoa, frente a frente, vendo ali os músculos do braço para fechar no caso de seu Beca, a disposição para falar por horas... Só essa senhora Neusa ela foi muito solícita e teve uma hora que eu desliguei, assim, porque já era mais de uma e tanta da manhã e ela continuou falando lá. Não me lembro de todos os nomes, nem os citei para preservar as pessoas. No caso do seu Beca, que havia morrido, mencionei lá o nome dele, o Osvaldão é mencionado no conto, alguns guerrilheiros também, a Laura...

Jacielle: Embora creia que de certo modo já falou disso, nessa última pergunta, gostaríamos de saber o porquê de seu interesse nesse assunto em particular, o da Guerrilha do Araguaia.

Janailson Macêdo: É muito interessante essa última pergunta, porque eu falei da experiência, mas não falei ainda por que ativar essas experiências.

Infelizmente, no Sul e Sudeste do Pará, há a questão das memórias de muitas histórias de violência. Ali dá pra escolher se você quer falar do que foi vivenciado pelos sem-terra, dos sindicatos rurais, em Rio Maria, esse próprio caso da Irmã Dorothy. São muitas atrocidades no período da história recente, com os indígenas. Inclusive, no meu próximo livro, a ideia é um pouco ativar essas outras memórias.

Mas por que a guerrilha? Essa questão da memória me chamou muita atenção, vivendo ali em Marabá. Houve um dia quando estava num táxi, logo nos primeiros dias na região, quando peguei um táxi na universidade. De repente, o taxista me veio falar do Osvaldão, das memórias da Guerrilha. Houve o depoimento do senhor que inspirou de certo modo o "Fantasma da Casa Azul”. Uma pessoa que é ligada a esse senhor estava no almoço lá na Velha Marabá e soltou: "Tal conhecido carregou cabeças na época da Guerrilha do Araguaia". A memória desse senhor é pública. Ele teria colaborado com os militares na locomoção de corpos, de presos políticos em centros clandestinos de aprisionamento, como a Casa Azul.

\footnotetext{
${ }^{24}$ Zezinho do Araguaia, codinome de Micheas Gomes de Almeida, militante histórico do PCdoB e participante da Guerrilha do Araguaia, sendo um dos primeiros a chegar e na região e um dos poucos a sair vivo após o início do massacre final no ano de 1973.
} 
É, portanto, uma temática com que você pode ter contato na rua, num táxi ou num almoço. Na antropologia, tem o Marcel Mauss, que fala do "fato social total". É muito interessante porque a Guerrilha de certa forma representou um pouco o fato social total para essas pessoas, ou seja, percebi que dialogar com essas memórias poderia gerar uma produção literária interessante porque aí você tem uma realidade que as pessoas vivenciaram. Quando você disse que a leitura de meu livro ativou sua memória, fico muito feliz de ouvir essa narrativa sua. Sei que o livro tem suas limitações e ainda tem que melhorar para uma futura edição que pretendo lançar. Penso como é que esse livro ele pode de repente ativar outras memórias e, como você, outras pessoas me deram feedbacks que eu achei interessantes.

Por que o Araguaia? Por isso, porque foi um fato social total e, que ainda existe. Ainda são muito fortes as memórias em relação ao que aconteceu e, com isso, com as memórias, as experiências também. Então, ou seja, de certa forma ativar um pouco essas memórias, ativar um pouco essas experiências, certamente que visando a questão de justiça social.

Não acredito naquela ideia de uma literatura eminentemente política no sentido de você pertence, está vinculado a um partido. Não sou vinculado a nenhum partido político. É mais no sentido da justiça social, para poder mostrar essas histórias de violência e fazer com que se aumentem as reflexões a respeito delas, para que também não mais aconteça esse tipo de coisa. Se os próprios militares aprendessem com essas experiências, abrissem os arquivos que ainda estão fechados, não para uma revanche ou algo do tipo, mas pra que essas experiências possam ser conhecidas, para que o efeito da violência a que elas fazem referência seja minimizado...

A gente sabe que a região do Pará, ou a região do Bico do Papagaio, no norte do Tocantins, assim como em outras partes do Pará, do Tocantins, do Maranhão, da Amazônia, do Nordeste, do Brasil, da América Latina e outros espaços, a violência que ocorreu na Guerrilha do Araguaia vem sendo muito presente ainda nos dias de hoje em outros formatos.

Penso que uma motivação é poder produzir uma obra literária em que se inserisse nessa relação, como um desafio, com diálogo com outras obras. A gente quer que a obra seja lida, que as pessoas deem atenção, pois o escritor também produz para ser lido.

Recebido em 24 de abril de 2020

Aprovado em 26 de abril de 2020 